\title{
Study on the Meiofauna Community Structure in Sajafi Shores as the Bio-Indicator of Environmental Pollution
}

\section{Tahmineh Taheri Dezfouli' ${ }^{1}$, Seyed Mohammad Bagher Nabavi², Ebrahim Rajabzadeh Ghatromi' Nooshin Sajjadi ${ }^{4}$}

${ }^{1}$ Islamic Azad University, North Tehran branch, Tehran, Iran

${ }^{2}$ Faculty of Marine Sciences, Khorramshahr University of Marine Science and Technology, Iran

${ }^{3}$ Department of Natural Resources, Khorramshahr University of Marine Science and Technology, Iran

${ }^{4}$ School of Marine Science and Technology, Islamic Azad University, North Tehran Branch, Tehran, Iran

Email: ttaheri1387@gmail.com,nabavishiba@yahoo.com,e.rajab@yahoo.com,nooshinsadjadi@yahoo.com

How to cite this paper: Dezfouli, T.T., Nabavi, S.M.B., Ghatromi, E.R. and Sajjadi, N. (2016) Study on the Meiofauna Community Structure in Sajafi Shores as the BioIndicator of Environmental Pollution. Open Journal of Ecology, 6, 632-644. http://dx.doi.org/10.4236/oje.2016.610059

Received: July 28, 2016

Accepted: September 27, 2016

Published: September 30, 2016

Copyright $\odot 2016$ by authors and Scientific Research Publishing Inc. This work is licensed under the Creative Commons Attribution International License (CC BY 4.0).

http://creativecommons.org/licenses/by/4.0/

(c) (i) Open Access

\begin{abstract}
In order to investigate the health of the coastal environments, we collected Meiofauna assemblages along intertidal muddy shores of Sajafi in the northwest of Persian Gulf in two seasons (February 2013 and July 2014) from three horizontal transects. Meiofauna are the metazoan components of the benthos, defined by their body size $(<500 \mu \mathrm{m})$ and are the most diversified elements of the marine biota. They are so sensitive against adverse environmental changes and represent the ecological conditions. Environmental factors (temperature, salinity, $\mathrm{DO}$, and $\mathrm{pH}$ ), diversity and distribution of Meiofauna and their relationship with each other and with the grain size and TOM in both cold and warm seasons were evaluated. In this study, 56 meiofaunal species were identified in which foraminifera were abundant. The result of Shannon-Wiener in summer 2014 showed the highest value $\left(\mathrm{H}^{\prime}=3.148\right)$ while the lowest value occurred in winter $2014\left(\mathrm{H}^{\prime}=1.5\right)$. At the same time, the highest and lowest values of Simpson index $(\lambda)$ were 0.43 and 0.05 respectively. Sajafi area, according to the Welch model, has a moderate $\left(\mathrm{H}^{\prime}=1-3\right)$ to unpolluted $\left(\mathrm{H}^{\prime}>3\right)$ condition compared to neighboring regions.
\end{abstract}

\section{Keywords}

Meiofauna, Benthic, Sajafi Area, Bio-Indicator, Persian Gulf

\section{Introduction}

Since human health depends on moving, development and application of ecosystems, 
loss of ecosystem components such as clean air, potable water and more, tightly focused our attention on the health of natural ecosystems. As almost all species can tolerate only a limited range of changes in chemical, physical and biological conditions, they tend to assess the quality of the environmental parameters [1]. Meiofauna formed one of the major groups of benthic metazoan organisms, larger than 100 microns and smaller than 500 micrometers, in the bed of oceans and seas, 82 percent of which are present at the 3 $\mathrm{cm}$ surface of the substrate [2]. They are most diversified elements of the marine biota [3].

Benthic Meiofauna are important members of coastal ecosystems and estuaries that fed by micro Algal and bacteria, affect the primary production cycle and bio mineralization and other parts of benthic metabolism [4]-[8]. Due to great abundance, low mobility, rapid replication, short life cycle, and extreme sensitivity to entering materials, Meiofauna are most appropriate bio-indicators of health of the marine environment [9] [10]. The major groups of benthic Meiofauna are Foraminifera, Ostracoda, Nematoda, Gastropoda, bivalve's larvae, larval shellfish, foam kits, and tube worms.

Meiofauna's close relationship with the environment wherein they grow, considered them as an important tool for biomonitoring the environmental parameters such as temperature, salinity, substrate type and concentration of different elements in the water and sediment [11] [12]. The presence of these organisms on the seabed is particularly susceptible to stress-related deposits [13].

The overall objective of this study was to investigate the possibility of using meiofaunal benthic communities as a bio-indicator of environmental pollution. By comparing the diversity in different areas, environmental situation and potential contamination of the region can be realized [14].

Drawing a clear picture of the environmental situation in the Persian Gulf due to increased tanker traffic, release of ballast water, exposure to many environmental threats, always was a concern for environmentalists. The Persian Gulf is a marginal basin in the extreme northwest of the Indian Ocean, affected mainly by the extra-tropical weather systems from the northwest [15]. The most well-known weather phenomenon is the Shamal, a Northwest wind which occurs year round [16] [17]. Water retention time in the Persian Gulf is estimated between 2 and 5 years [18]. The salinity ranges between 27 and $41 \mathrm{mg} / \mathrm{l}$ by temperature more than $20^{\circ} \mathrm{C}$ [19] [20]. Because of high evaporation, and therefore high salinity, surface sediments in Persian Gulf become smaller from the beach to the depth. Limestone marl is the recent deepest facies of Persian Gulf [21].

Sajafi area in the northern Persian Gulf (Figure 1) biologically has some features that cause certain plant and animal communities in the region to be seen.

[22] had studied the distribution of Meiofauna in the south coast of East India. The results show that human disturbances and pollution influence species diversity in coastal intertidal areas. They study Meiofauna that can be important indicators of overall productivity of fish. [23] had introduced Meiofauna as a tool for the study of marine ecosystems. [24] had evaluated several indicators of Meiofauna in the sediments of three Mediterranean harbors with different environmental conditions in order to estimate the 


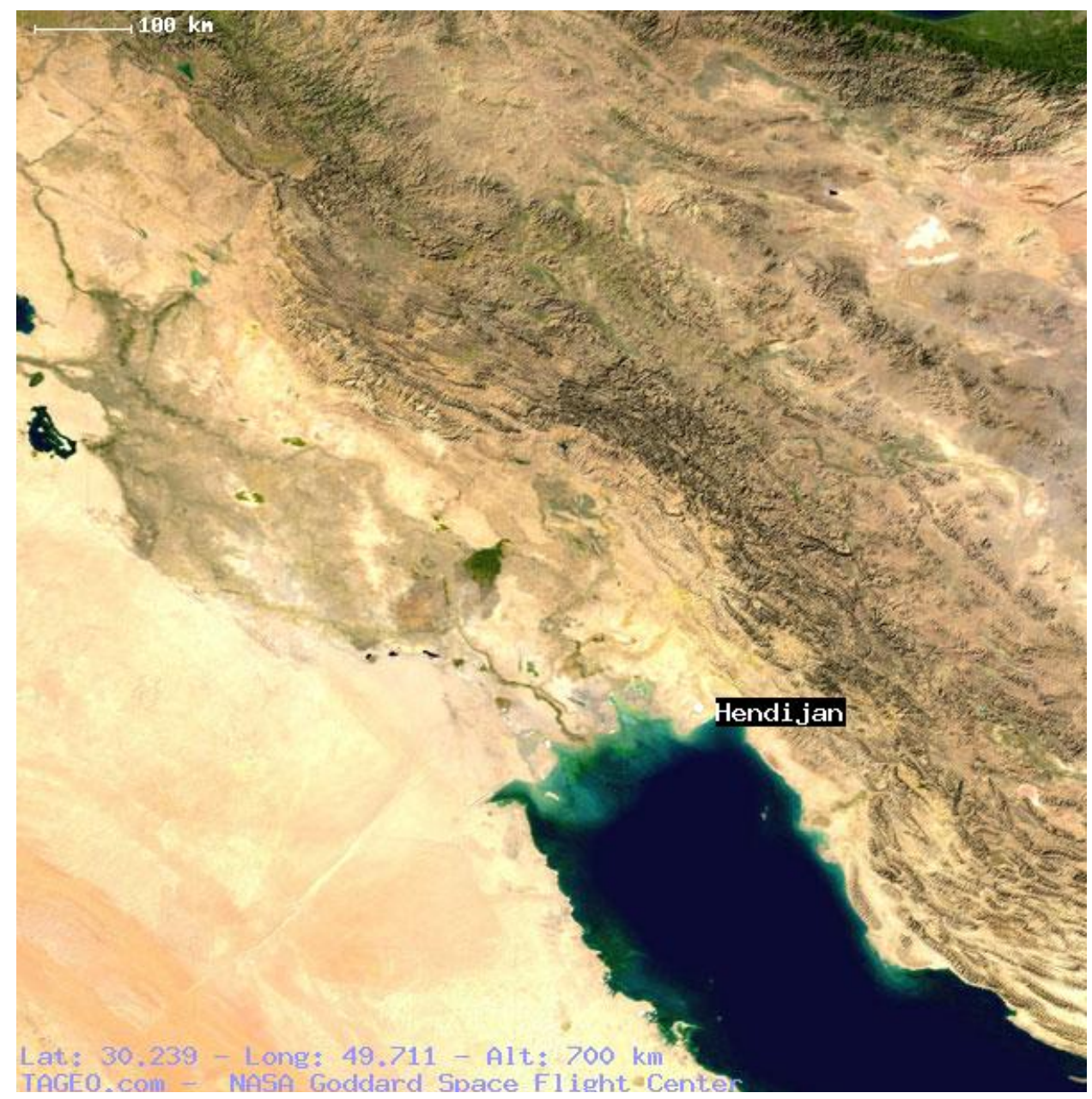

Figure 1. Location map of sampling and overview on sampling sites.

effectiveness and identify the types of pollution index that describes better the quality of the environment. The relationship between indices based on specific taxa Meiofauna with pollutant concentrations, especially polycyclic aromatic hydrocarbons (PAHs) has been accessed [25] and provided a report on the Meiofauna in protected Mangrove forests area in the Persian Gulf. The results showed that the foraminifera were dominant societies. [26] conducted a qualitative study on Mayobentoz in the Persian Gulf. In a qualitative study on nematodes, then, Foraminifera, Cope Poda, Polychaeta and Oligochaeta were dominant, respectively.

Meiofauna's rich and diverse communities in this study show that they can be used in the future plans of environmental monitoring, marine pollution and study the food chain.

\section{Materials and Methods}

The study area is located on Sajafi intertidal beaches in the north Persian Gulf, south to southwest Hendijan city in Khuzestan province, Iran (Figure 1). Sampling in both cold seasons (February 2013; average temperature $14.74^{\circ} \mathrm{C}$ ) and warm (July 2014; average temperature $31.9^{\circ} \mathrm{C}$ ) was conducted. To determine the position of three transects and 3 
stations in each, a satellite positioning system (GPS) was used (Table 1).

First, surface sediment was sampled at each station with a Van Veen Grab crosssection 0.025 square meters. Then, with the cylindrical in diameter and height of $3 \mathrm{~cm}$, sediment sampling with three replications was conducted.

To prevent the corruption of living species, the samples were fixed in formalin $5 \%$ to reach up to the lab were stored in polyethylene containers. Water from the adjacent seabed at each station immediately picked up and by the sensors of environmental parameters, temperature, salinity, $\mathrm{DO}$ and $\mathrm{pH}$ were measured in the field, each with three replications. A sample from each station, about 200 to 300 grams wet sediment in separate polyethylene containers for grain study and the total organic matter (TOM) sediments were removed and kept in plastic bags and transported to the laboratory on ice. To measure the total amount of organic matter in sediments, combustion method [27] were used. The standard method to determine the grain size distributions of passing a series of sieves [28] was used.

To extract Meiofauna in the laboratory, the stabilized sediments by using a sieve of 5.0 and 63 microns ( $5.0 \mathrm{~mm}$ sieve above and below 63 microns) were washed and then Meiofauna samples were stained by 1 gram per liter solution of Rose Bengal. In order to isolate shellfish Meiofauna, the container to container method was used and samples were identified and counted by optical microscopy [29]. All Meiofauna were identified to genus based on the pictorial keys of [30], the online information system WoRMS [30] [31].

In order to calculate the relationship between environmental factors and Meiofauna density in all seasons and stations, basic statistical correlation coefficient is used. Statistical analysis of the data was carried out using SPSS (version 19). Differences between controls and treatments were compared by parametric one-way ANOVA tests (significance level of $\alpha=0.05)$. A posteriori paired multiple-comparisons were performed

Table 1. Station coordinations.

\begin{tabular}{ccc}
\hline & \multicolumn{2}{c}{ Coordinate 39 R } \\
\cline { 2 - 3 } Station & $\mathrm{N}$ & $\mathrm{E}$ \\
\hline T1-St1 & $30^{\circ} 45^{\prime} 10^{\prime \prime}$ & $49^{\circ} 37^{\prime} 2.95^{\prime \prime}$ \\
T1-St2 & $30^{\circ} 45^{\prime} 11^{\prime \prime}$ & $49^{\circ} 37^{\prime} 21.68^{\prime \prime}$ \\
T1-St3 & $30^{\circ} 45^{\prime} 11^{\prime \prime}$ & $49^{\circ} 37^{\prime} 32.12^{\prime \prime}$ \\
T2-St1 & $30^{\circ} 36^{\prime} 96^{\prime \prime}$ & $49^{\circ} 36^{\prime} 43.27^{\prime \prime}$ \\
T2-St2 & $30^{\circ} 0^{\prime} 25.59^{\prime \prime}$ & $49^{\circ} 36^{\prime} 43.29^{\prime \prime}$ \\
T2-St3 & $30^{\circ} 0^{\prime} 16.66^{\prime \prime}$ & $49^{\circ} 36^{\prime} 46.10^{\prime \prime}$ \\
T3-St1 & $30^{\circ} 0^{\prime} 11^{\prime \prime}$ & $49^{\circ} 36^{\prime} 29.23^{\prime \prime}$ \\
T3-St2 & $30^{\circ} 0^{\prime} 11.78^{\prime \prime}$ & $49^{\circ} 36^{\prime} 30.18^{\prime \prime}$ \\
T3-St3 & $30^{\circ} 0^{\prime} 9.34^{\prime \prime}$ & $49^{\circ} 36^{\prime} 35.80^{\prime \prime}$ \\
\hline
\end{tabular}


using Tukey HSD test. Relation between various metals was established via Pearson correlation.

To calculate the species diversity and dominance the Shannon diversity index (H) based on the natural logarithm (ln); N2 $=1 / \lambda$, where $\lambda$ is Simpson's dominance index; to calculate the species richness Menhinic index and to express the species dispersal among the area of study, the Hill's evenness index was used respectively, all using the PAST V.1 [1]-[15]. To realize the situation in the region in terms of diversity and pollution, Welch model 1992 was used.

\section{Results}

With the aim of tracking the effects of pollution, identification as top groups (genus, family, class, order) took place. In this study, a total of 56 species in the warm season and, 48 species in the cool season belonging to 31 genera were observed, the highest species diversity in foraminifera, gastropods and Ostracoda and Nematodes were seen. The greatest number of species related to foraminifera and then high species diversity belongs to Ostracoda and Gostropoda. Ammonia beccarii species in all stations were abundant with a significant difference $(\mathrm{p}<0.005)$ from other Meiofauna.

According to Figure 2, most frequency of Meiofauna in the warm season was in T1S3 station and the lowest was observed in T2S2 station. In the cold season, a significant difference can be seen in the first Transect stations, so that the highest frequency and lowest was in T1S2, T1S1 respectively.

In all three transects studied in the warm season in 2014, DO and temperature were not significantly different $(\mathrm{p}>0.05)$. Water salinity in T3S1 station is less than other stations. The average salinity from $0.31 \pm 43.18$ in the warm season to $0.18 \pm 38.05$ in the cold season has been measured (Table 2). Changes in sampling sites showed significant differences in different seasons. In the cold season temperature and $\mathrm{pH}$ at three stations ( $p>0.05$ ) were not significantly different. The highest percentage of aggregate deposits was $0.063>\mathrm{mm}$ in the warm season in T2-S3 stations and the amount of $99.53 \%$ and the lowest percentage in T3-S3 Station and the amount of $81.271 \%$, respectively.

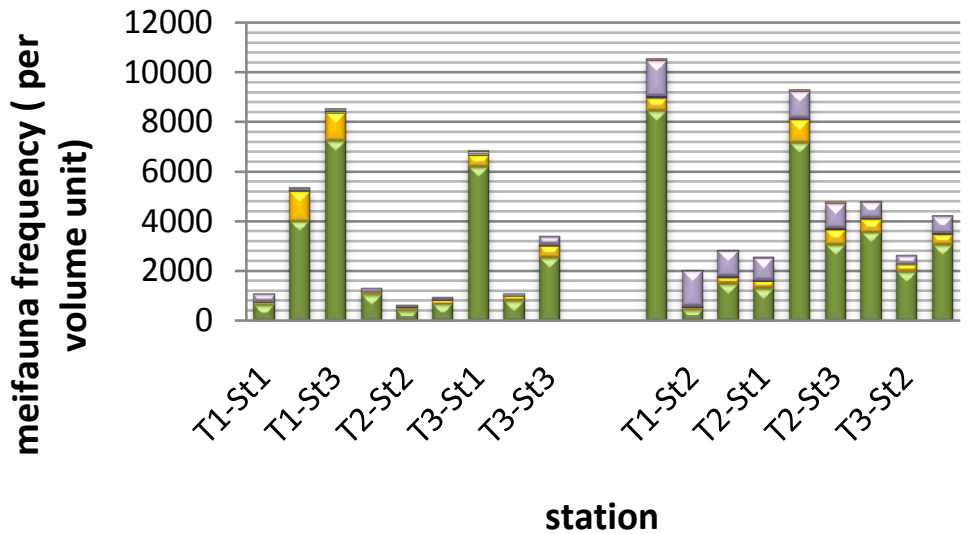
$\square$ chironomid
$\square$ Polychaeta
Bivalvia
$\square$ Nematoda
- Copepoda
$\square$ Gastropoda
$\square$ Ostracoda
Foraminifera

Figure 2. Comparison Meiofauna frequency separating in sampling sites in both summer and winter seasons. 
Table 2. Mean environmental parameters, total organic matter content and aggregation stations in the two warm and cold seasons.

\begin{tabular}{ccc}
\hline & Summer & Winter \\
\hline Temperature $\left({ }^{\circ} \mathrm{C}\right)$ & $31.90 \pm 1.04 \mathrm{a}$ & $14.75 \pm 0.10 \mathrm{~b}$ \\
$\mathrm{DO}(\mathrm{mg} / \mathrm{L})$ & $4.42 \pm 0.95 \mathrm{a}$ & $8.36 \pm 1.07 \mathrm{~b}$ \\
$\mathrm{pH}$ & $7.91 \pm 0.002 \mathrm{a}$ & $7.92 \pm 0.43 \mathrm{a}$ \\
$\mathrm{TOM}(\%)$ & $15.72 \pm 3.32 \mathrm{a}$ & $12.16 \pm 1.93 \mathrm{~b}$ \\
Salinity $(\mathrm{mg} / \mathrm{L})$ & $43.18 \pm 0.31 \mathrm{a}$ & $38.05 \pm 0.18 \mathrm{~b}$ \\
Grain size $>\mathbf{0 . 1 2 5}(\%)$ & $4.1 \pm 5.9 \mathrm{a}$ & $0.405 \pm 0.509 \mathrm{a}$ \\
Grain size $\mathbf{0 . 0 6 3}-\mathbf{0 . 1 2 5 ( \% )}$ & $0.58 \pm 0.337 \mathrm{a}$ & $0.887 \pm 0.51 \mathrm{a}$ \\
Grain size $<\mathbf{0 . 0 6 3 ( \% )}$ & $95.3 \pm 6.2 \mathrm{a}$ & $98.7 \pm 0.72 \mathrm{a}$ \\
\hline
\end{tabular}

Dissimilar letters indicate significant differences $(\mathrm{p}<0.05)$.

The highest percentage of aggregate deposits in the cold season was $0.063>\mathrm{mm}$ in T3-S3 stations with the amount of $99.621 \%$ and the lowest percentage in the station T1-S1 with the amount of $97.568 \%$.

The mean percentage of total organic matter was obtained in the sediments in the warm season $32.3 \pm 72.15$ and in the cold season $93.1 \pm 16.12$ (Table 2). There is a negative correlation between most Meiofauna species in winter with total organic matter content (at 0.01 and 0.05 ), but in the hot season there is a negative correlation between Bivalves and the percentage of total organic matter at 0.05 level (Table 3 ).

To show the correlation between Meiofauna frequency and organic matter in two hot and cold seasons, in summer all stations had a negative correlation at 0.01 with percentage of total organic matter (Table 4).

Among the three selected Transects the most dominance was in the T2 and the lowest in T1, most indicators of diversity value among T1 and the lowest in T2, greatest Menhinic enrichment and Hill evenness values in T2 and the lowest were seen in T1 (Table 5).

T1S1 station has the most dominance in summer (00.17) that the figure in winter reduced to 00.11 . In winter most dominant index in T1S2 station and approximately was 00.4 that show a sharp increase in dominant and reducing the diversity in the hot season. Shannon index at all stations between 1 and 3 were calculated at several stations (stations T1S2 and T3S1 in summer) values above 3 obtained and conditions in the region in terms of pollution compared to the Welch model, partially semi-infected were detected (Table 6). Diversity indices showed no correlation with any of the environmental parameters.

\section{Discussion and Conclusion}

In any ecosystem, if there is no stress on ecosystems, specified seasonal and time changes in the major physical and chemical parameters of water and sediments are the 
Table 3. Correlation between environmental parameters and frequency bands of Meiofauna in the cold season 2014 and warm season 2014.

\begin{tabular}{|c|c|c|c|c|c|c|c|c|c|c|c|c|c|c|}
\hline & \multicolumn{2}{|c|}{ Temperature } & \multicolumn{2}{|r|}{ EC } & \multicolumn{2}{|c|}{ DO } & \multicolumn{2}{|c|}{$\mathrm{pH}$} & \multicolumn{2}{|c|}{ TOM } & \multicolumn{2}{|c|}{ salinity } & \multicolumn{2}{|c|}{$\begin{array}{c}\text { Grain } \\
\text { size }<0.063(\%)\end{array}$} \\
\hline & Winter & Summer & Winter & Summer & Winter & Summer & Winter & Summer & Winter & Summer & Winter & Summer & Winter & Summer \\
\hline Foraminifera & -0.050 & 00 & -0.037 & -0.373 & 0.151 & -0.291 & -0.223 & $-0.463^{\star}$ & $-0.439^{\star}$ & -0.270 & 0.058 & 0.231 & -0.109 & 0.016 \\
\hline Ostracoda & -0.058 & 00 & -0.037 & $-0.723^{\star *}$ & 0.15 & 0.013 & -0.22 & $-0.685^{\star *}$ & $0.430^{*}$ & 0.074 & 0.057 & 0.083 & 0.295 & -0.210 \\
\hline Nematoda & 0.292 & 00 & -0.208 & 0.041 & 0.293 & 0.301 & -0.145 & 0.190 & $-0.415^{\star}$ & -0.274 & 0.096 & 0.162 & -0.506 & 0.085 \\
\hline $\begin{array}{l}\text { harpacticoida } \\
\text { copepoda sp. }\end{array}$ & 0.112 & 00 & 0.010 & $-0.468^{\star}$ & 0.313 & 0.165 & -0.225 & -0.198 & $-0.586^{\star *}$ & 0.138 & -0.007 & 0.015 & $-0.692^{\star}$ & 0.240 \\
\hline
\end{tabular}

${ }^{\star}$ Correlation at $0.05{ }^{* *}$ Correlation at 0.01 .

Table 4. Correlation between environmental parameters and frequency of Meiofauna in the cold and warm season 2014.

\begin{tabular}{|c|c|c|c|c|c|c|c|c|c|c|c|c|c|c|}
\hline \multicolumn{2}{|c|}{$\begin{array}{c}\text { Grain } \\
\text { size }<0.063(\%)\end{array}$} & \multicolumn{2}{|c|}{ Salinity } & \multicolumn{2}{|c|}{ TOM } & \multicolumn{2}{|c|}{$\mathrm{pH}$} & \multicolumn{2}{|c|}{ DO } & \multicolumn{2}{|c|}{ EC } & \multicolumn{2}{|c|}{ Temperature } & \\
\hline Summer & Winter & Summer & Winter & Summer & Winter & Summer & Winter & Summer & Winter & Summer & Winter & Summer & Winter & \\
\hline 0.308 & 0.853 & 0.149 & 0.286 & $-0.708^{\star *}$ & 0.276 & -0.162 & 0.104 & 0.407 & 0.082 & 0.017 & -0.120 & $0 / 000$ & -0.124 & T1S2 \\
\hline 0.267 & 0.588 & 0.217 & -0.211 & $-0.759^{* *}$ & -0.438 & -0.110 & -0.072 & 0.336 & $0.508^{*}$ & 0.081 & 0.099 & $0 / 000$ & 0.313 & T1S3 \\
\hline-0.556 & -0.981 & 0.360 & $-0.474^{\star}$ & $-0.732^{\star \star}$ & $-0.502^{*}$ & -0.099 & 0.053 & 0.391 & $0.586^{*}$ & 0.139 & 0.211 & $0 / 000$ & $0.629^{* *}$ & $\mathrm{~T} 2 \mathrm{~S} 2$ \\
\hline-0.521 & 0.948 & 0.050 & -0.236 & $-0.607^{\star *}$ & -0.441 & 0.073 & -0.071 & 0.333 & $0.594^{* *}$ & 0.102 & 0.183 & $0 / 000$ & $0.619^{* *}$ & $\mathrm{~T} 2 \mathrm{~S} 3$ \\
\hline 0.888 & -0.01 & 0.384 & -0.317 & $-0.815^{\star *}$ & $-0.762^{\star *}$ & -0.096 & -0.275 & 0.223 & $0.569^{*}$ & 0.085 & 0.187 & $0 / 000$ & 0.401 & T3S1 \\
\hline-0.708 & 0.818 & 0.285 & $-0.479^{\star}$ & $-0.707^{\star *}$ & $-0.604^{\star *}$ & -0.131 & -0.031 & 0.427 & $0.6090^{* *}$ & 0.080 & 0.215 & $0 / 000$ & $0.570^{*}$ & T3S2 \\
\hline
\end{tabular}

${ }^{\star}$ Correlation at $0.05{ }^{* *}$ Correlation at 0.01 .

Table 5. Evaluation of biological indicators in T1, T2, T3 transects in the winter 2014 and summer 2014.

\begin{tabular}{|c|c|c|c|c|c|c|}
\hline $\begin{array}{c}\text { Transect } \\
\text { index }\end{array}$ & \multicolumn{2}{|c|}{$\mathrm{T} 1$} & \multicolumn{2}{|c|}{$\mathrm{T} 2$} & \multicolumn{2}{|c|}{$\mathrm{T} 3$} \\
\hline Simpson dominance index & 0.137 & 0.111 & 0.120 & 0.14 & 0.140 & 0.138 \\
\hline Simpson diversity index & 0.862 & 0.888 & 0.879 & 0.86 & 0.859 & 0.868 \\
\hline Menhinick index & 0.687 & 0.821 & 0.717 & 1.6 & 0.818 & 0.941 \\
\hline Hill evenness index & 0.264 & 0.32 & 0.551 & 0.33 & 0.276 & 0.29 \\
\hline
\end{tabular}

most important factors in generating a sequence of changes in the composition of species and communities. Human activities such as industry, agriculture, mining, dredging and sewage discharge large amounts of pollutants into the marine environments; causing obvious temporary impairments and imposing enormous impact on the ecosystem. 
Table 6. Compare diversity index stations with Welch model in winter and summer 2014.

\begin{tabular}{ccccc}
\hline & \multicolumn{2}{c}{ Winter } & \multicolumn{2}{c}{ Summer } \\
Station & $\begin{array}{c}\text { Shanon wiener } \\
\text { diversity index }\end{array}$ & Condition & $\begin{array}{c}\text { Shanon wiener } \\
\text { diversity index }\end{array}$ & Condition \\
\hline T1S1 & 2.69 & moderate & 2.47 & Moderate \\
T1S2 & 1.58 & Moderate & 3.148 & unpolluted \\
T1S3 & 2.44 & Moderate & 2.694 & Moderate \\
T2S1 & 2.51 & Moderate & 2.579 & Moderate \\
T2S2 & 2.75 & Moderate & 2.739 & Moderate \\
T2S3 & 2.77 & Moderate & 2.868 & Moderate \\
T3S1 & 2.171 & Moderate & 3.21 & unpolluted \\
T3S2 & 2.705 & Moderate & 2.849 & Moderate \\
T3s3 & 2.49 & moderate & 2.897 & moderate \\
\hline
\end{tabular}

$\mathrm{H}^{\prime}>3$ Unpolluted; $\mathrm{H}^{\prime}=1$ - 3 Moderate; $\mathrm{H}^{\prime}<1$ Polluted.

Benthic communities generally respond to changes in ecological conditions [18]. Benthos study in the sediments of the sea is one of the most ecological phenomena. Meiofauna are considered as a food source for juvenile and higher marine trophic levels, as well as helping to recycle nutrients. They have oceanography, biology and geology features; therefore, identifying and determining the density and distribution of meiofaunal assemblages and their changes in different seasons and stations is important. Currently the most commonly method used in studies of the effects of pollution is community response test, which is a combination of all the species found in the region. According to the results of this study, it is inferred that the benthic condition of Persian Gulf is appropriate for Foraminifera because almost all stations surveyed, therefore foraminifera was the most abundant phylum (51.21\%), similar to results of Meiofauna study in Naiband shore (Persian Gulf) by [27]-[29]; and in the next sequence placed were the crustaceans, gastropods, nematodes and bivalves [30]. After that, Foraminifera, Cope Poda, Polychaeta and Oligochaeta were dominant.

Ammonia beccarii species in all stations was more abundant than other Meiofauna species, cosmopolitan species found in all marine ecosystems, estuaries, coastal lagoons and even in fresh water leading to the sea, well adapted to different salinities. In similar studies [27] reported this species in deposits of Nayband forests, Musa estuary, Hendijan beaches and even Zohreh River to distances far from the sea. Studies of [32] showed that the sediments along the northern continental shelf of Oman were the dominant species belonging to the Rotalina suborder.

Entzia sp. species are reported for the first time in the region. In addition to European rivers and lakes, this species has reported from the Gulf of Mexico, Mediterranean and the North East Atlantic [33] and likely by cargo ships and oil tankers ballast water that went to the area, entered the area beaches and is compatible with the northern coast of Persian Gulf, or that is native to the region but had not been reported [29].

To estimate the abundance and distribution pattern, the bio monitoring indices were 
applied. Comparing three transects in hot and cold weather, the highest Simpson dominance index value was observed in third transect that is closer to the mouth of the Zohreh River and the lowest was in the first transect. Close to zero values of dominance index and high value of of Shannon-Wiener diversity index $\mathrm{H}^{\prime}$ (near to 3 ) represent the high diversity in the region.

[30] in studying bivalves of Hendijan beaches reported most Shannon index value in the summer (0.29) and the lowest in autumn (0.044) and investigated Meiofauna in Naiband protected area in Persian Gulf (2008) maximum Shannon value 2.84 and minimum $\mathrm{H}$ 'to 1.421 obtained.

According to the results of Menhinic's enrichment index the studying area has high species richness. Hill's evenness index shown the distribution of species was not balanced and tend to a species (Ammonia Beccaria) was higher. Because of dominant species was higher in summer, Simpson index showed the highest value obtained in this chapter.

Dominance decreased with distance from the shoreline and diversity increased that due to intertidal conditions in the region was expected. Meiofauna is one of the most important communities of muddy sediment shores and are dependent on substrate properties [33].

Differences in sediment texture of sampling stations may be the most important factors in these areas are in conflict with the distribution pattern of benthos [27]-[30]. In this study, percent of silt and clay in winter is more than summer, that it could be due to seasonal rainfall and runoff and sedimentation in the sea.

None of the species showed any significant correlation with sediment and homogeneous soft-bottom, so they're not influencing factors on diversity of Meiofauna. The main food source for benthic Meiofauna (except endosymbiotic species) is organic materials (particularly fragments) and all the bacterial communities on which they are reproduced.

Increasing the amount of organic matter in coastal areas could increase the biomass of the benthic Foraminifera [27]-[34]. Amount of organic material in Sajafi area sediments was high that's probably because of the silt clay particle size in the region. Comparing reduction of organic matter in winter and summer can be due to primary producers, reducing bacteria, activities of most of the creatures on the beach and being smaller than the particle size in this season. [15] observed inverse relationship between species richness and the amount of intertidal sediments organic matter in Bushehr.

A negative correlation was found between Meiofauna and TOM amount that can be due to high levels of organic matter in sediments which affect the oxygen concentration [14]. Depletion of dissolved oxygen in summer observed.

Physical and chemical parameters influence on the composition and density of benthic environment. Totally the benthos population is controlled by a set of factors and not only a single on that can be considered as the main factor involved in the distribution of these organisms [8]-[28].

In the study area, the temperature changes between stations are surprisingly limited that it could be due to the close proximity to each sampling sites and not enough to 
have a significant effect on the distribution or Meiofauna density. But seasonal variations in temperature which has an impact on the amount of dissolved oxygen can cause the differences in population structure and Meiofauna species composition. Meiofauna communities in the cold season in four stations showed a positive correlation with temperature. Since intertidal muddy shores are under the influence of weather conditions such as drought and high heat rejection located, it could be created problems of lack of oxygen in the surface layers of sediments [2]. The results of this study indicate high levels of oxygen in the sediments. Reducing oxygen and increasing in salinity and temperature in the summer is important that the dissolution of gases correspond with chemical laws, as the amount of salinity and temperature will increase the solubility of oxygen in water is reduced. Salinity in muddy beds shows fewer changes than the rest of the context. Salinity between 43.3 - 38.4 in the ports of Hendijan measured by [29]. [5], considered the salinity and sediment structure as two significant factors influencing the structure of Mayobentoz communities. In winter, most species showed significant correlations with organic matter. In the warm season species richness and diversity increased. New species of gastropods were observed and since the amount of organic matter reduces the diversity and reduction in species diversity was observed in the cold season.

Nematodes in the cold season were much more plentiful than the warm season. Babachahi [20] in Bushehr on the Soltani estuaries and Lashkari in Persian Gulf coast has reported most frequency of Meiofauna in summer. [29] [30] in the Nayband coast have reported seasonal changes in Meiofauna communities because of correlation with environmental factors. With increasing depth in the cold season, species richness increased and in warm season decreased. This can be due to changing water temperature and Plankton activity that are the food source of Meiofauna [31]-[34]. In the winter, more fine-grain, reduced organic matter and increase dissolved oxygen was found. It can be concluded that the amount of organic matter and sediments grain size are important in determining the diversity and dispersion of Meiofauna. Compared with the Welch model, the area was found partially moderate and unpolluted, which it could be due to region conditions and the river output. According to Ropme technical report in the region, most physical pressures are demands of sailing activities and fishing. Finally, the results of this study showed that the species diversity in intertidal Sajafi coasts, located in the region Hendijan is high, indicating the relative stability of the environment. Diversity indices compared with similar regions had relatively high values. High organic matter content affects the Meiofauna communities. Physical and chemical environmental parameters such as salinity and dissolved oxygen, distribution and diversity of Meiofauna in Sajafi area have been influential and regional and seasonal changes have led to significant differences in diversity of Meiofauna. So Meiofauna can be used as a useful tool for monitoring the environmental situation in muddy shores.

\section{References}

[1] Aghanabati, A. (1999) Iran Jurassic Stratigraphy. Publication of the Ministry of Industry and Mines, Geological Survey of Iran, Tehran, 356 p. 
[2] Babachahy, M. and Kisomi, O. (2009) Investigating City of Bushehr on the Persian Gulf Coast Soltani Benthic Estuaries. Persian Gulf International Conference, Islamic Azad University of Bushehr, 17-19 December 2009, 45.

[3] Dehghan, F. (2005) Mtalh Structure and Composition of Faunal Groups as a Bio-Indicator of Pollution in Tidal Areas Meiofauna City of Bushehr. Master's Thesis, Islamic Azad University Science and Research Branch of Khuzestan.

[4] Nari Mesa, Q., Nabavi, M. and Pour, S. (2011) Ecological Capability of District Raphe Using GIS and Fuzzy Logic (GIS) Geographic. Environmental Studies, 2, 29-40.

[5] Alve, E. (1995) Benthic Foraminiferal Responses to Estuarine Pollution: A Review. Journal of Foraminiferal Research, 25, 190-203. http://dx.doi.org/10.2113/gsjfr.25.3.190

[6] Alves, A.S., Adão, H., Ferrero, T.J., Marques, J.C., Costa, M.J. and Patrício, J. (2013) Benthic Meiofauna as Indicator of Ecological Changes in Estuarine Ecosystems: The Use of Nematodes in Ecological Quality Assessment. Ecological Indicators, 24, 462-475. http://dx.doi.org/10.1016/j.ecolind.2012.07.013

[7] Balsamo, M., Semprucci, F., Frontalini, F. and Coccioni, R. (2012) Meiofauna as a Tool for Marine Ecosystem Biomonitoring. In: Dr. Cruzado, A., Ed., Marine Ecosystems, 25-45.

[8] Moghadasi, B., Nabavi, M., Fatemi, M. and Vosoghi, Gh. (2009) Comparison of Species Diversity and Distribution Patterns of Benthic Foraminifera in the Northern and Southern Continental Shelf of Oman. Journal Marine Biology from 0.13 to 27.

[9] Moghadasi, B., Nabavi, M., Fatemi, M. and Vosoghi, Gh. (2008) Ostracoda Species Diversity and Distribution Patterns and Benthic Sediments of the Continental Shelf in the Sea of Oman. Thesis, Islamic Azad University, Science and Research Branch of Tehran.

[10] Moghadasi, B., Nabavi, M., Sohrabi Mullah Yousefi, M. and Vosoghi (2012) Distribution of Benthic Foraminifera on the Southern Shore of the Caspian Sea between Mahmoud Abad Light. National Conference of Aquatic Ecosystems, Iran.

[11] Mirzajani, A., Yousef Zadeh, A., Sayadrahim, M. and Abdolmaleki (2002) Reviews: Meiofauna and Features Bed Gilan on the Caspian Sea Waters. Journal of Fisheries of Iran (Fars), 11, 119-132.

[12] Nabavi, S.A. (1991) Persian Gulf Benthic Studies. Project Number 203, the Research Department of Shahid Chamran University.

[13] Nabavi, S.A. (1992) Mayvfvnhay Study Persian Gulf and Its Relation with Some Ecological Factors. Proceedings of the Second Congress of Water and Atmospheric Science and Technology of Iran, Shahid Chamran University, Iran.

[14] Bernhard, J.M. and Sen Gupta, B.K. (1999) Foraminifera in Oxygen-Depleted Environments. In: Sen Gupta, B.K., Ed., Modern Foraminifera, Kluwer, Dordrecht, 201-216. http://dx.doi.org/10.1007/0-306-48104-9_12

[15] Gehrels, W.R. and van de Plassche, O. (1999) The Use of Jadammina macrescens (Brady) and Balticammina pseudomacrescens Bronnimann, Lutze and Whittaker (Protozoa: Foraminiferida) as Sea-Level Indicators. Palaeogeography, Palaeoclimatology, Palaeoecology, 149, 89-101. http://hdl.handle.net/1871/29490 http://dx.doi.org/10.1016/S0031-0182(98)00194-1

[16] Manini, E., Gambi, C., Danovaro, R. and Fabiano, M. (2000) Meiobenthic Grazing Rates on Bacteria and Microphytobenthos in the Northern Adriatic Sea: Preliminary Results. Biologia Marina del Mediterraneo, 7, 233-238.

[17] De Meira, J., Moura, R. and Garraffoni, R.S. (2013) Lotic Meiofauna Communities as Bio-Indicators of Aquatic Pollution in the State Park, Minas Gerais State, Brazil. Australian Journal of Basic and Applied Sciences, 7, 991-1003. 
[18] Moreno, M., Vezzulli, L., Marin, V., Laconi, P., Albertelli, G. and Fabiano, M. (2008) The Use of Meiofauna Diversity as an Indicator of Pollution in Harbours. ICES Journal of Marine Science, 65, 1428-1435. http://icesjms.oxfordjournals.org/ http://dx.doi.org/10.1093/icesjms/fsn116

[19] Moreno, M., Semprucci, F., Vezzulli, L., Balsamo, M., Fabiano, M. and Albertelli, G. (2011) The Use of Nematodes in Assessing Ecological Quality Status in the Mediterranean Coastal Ecosystems. Ecological Indicators, 11, 328-336. http://dx.doi.org/10.1016/j.ecolind.2010.05.011

[20] Mostafawi, N., Nabavi, S.M.B. and Moghaddasi, B. (2010) Ostracods from the Strait of Hormuz and Gulf of Oman, Northern Arabian Sea. Revista Española de Micropaleontología, 42, 243-265.

[21] Simpson, E.H. (1949) Measurement of Diversity. Nature, 163, 688. http://dx.doi.org/10.1038/163688a0 Tan, T.K. and Lim, G. (1984) A Comparison of Fungi from Polluted Water. Environmental Pollution Series A, 35, 57-65. http://dx.doi.org/10.1016/0143-1471(84)90130-2

[22] Suderman, K. and Thistle, D. (2003) Spills of Fuel Oil \#6 and Orimulsion Can Have Indistinguishable Effects on the Benthic Meiofauna. Marine Pollution Bulletin, 46, 49-55. http://dx.doi.org/10.1016/S0025-326X(02)00235-7

[23] Varadharajan, D. and Soundarapandian, P. (2013) Meiofauna Distribution from Arukkattuthurai to Aiyyampattinam, South East Coast of India. Open Access Scientific Reports, 2, 682.

[24] Warwick, R.M. and Gee, J.M. (1984) Community Structure of Estuarine Meiobenthos. Marine Ecology Progress Series, 18, 97-111. http://dx.doi.org/10.3354/meps018097

[25] Watkins, J.G. (1961) Foraminiferal Ecology around the Orange County, California, Ocean Sewer outfall. Micropaleontology, 7, 199-206. http://dx.doi.org/10.2307/1484279

[26] Welch, E.B. (1992) Ecological Effects of Wastewater Applied limnology and Pollutant Effects. Taylor \& Francis E-Library, London.

[27] Nabavi, S.M.B., Yavari, V., Kochanian, P., Sabzkabayi, G., Molla, A. and Ashrakian, N. (2008) Meiofauna of Mangrove in the Naiband Protected Area (Persian Gulf). National Academy Science Letters, 31, 233-239.

[28] Nabavi, S.M.B., Ghotbeddin, N., Kochanian, P. and Dehghan Madise, S. (2007) Studies on Dominant Bivalve Populations of Hendijan Coast (Persian Gulf). National Academy Science Letters, 31, 297-303.

[29] Nabavi, S.M.B. (2013) Meiobenthos in the ROMPE Sea Area. Technical Report Series, Ropme Oceanographic Cruise.

[30] Pinckney, J.L., Carman, K.R., Lumsden, S.E. and Hymel, S.N. (2003) Microalgal-Meiofaunal Trophic Relationships in Muddy Intertidal Estuarine Sediments. Aquatic Microbial Ecology, 31, 99-108. http://dx.doi.org/10.3354/ame031099

[31] Pourjomeh, F., Hakim Elahi, M., Rezai, H. and Chegini, V. (2013) A Qualitative Study on Meiobenthos Organisms with the Emphasis on Efficient Sorting Methods in the Persian Gulf. International Conference on Oceanography \& Sustainable Marine Production: A Challenge of Managing Marine Resources under Climate Change (ICOSMaP), Kuantan, 28-30 October 2013, 65.

[32] Purser, B.H. and Seibold, E. (1973) The Principal Environmental Factors Influencing Holocene Sedimentation and Diagensis in the Persian Gulf, Holocene Carbonate Sedimentation and Diagenesis in a Shallow Epicontinental Sea. Springer-Verlag, Berlin, 1-11, 199-211.

[33] Michael, R.R. (1993) Physical Oceanography of the Persian Gulf, Strait of Hormuz, and the 
Gulf of Oman-Results from the Mt. Mitchell Expedition, Submitted to the Marine Pollution Bulletin, Pergamon Press, London.

[34] Shannon, C.E. and Weaver, W. (1963) The Mathematical Theory of Communications. University of Illinois Press, Urbana.

Submit or recommend next manuscript to SCIRP and we will provide best service for you:

Accepting pre-submission inquiries through Email, Facebook, LinkedIn, Twitter, etc. A wide selection of journals (inclusive of 9 subjects, more than 200 journals)

Providing 24-hour high-quality service

User-friendly online submission system

Fair and swift peer-review system

Efficient typesetting and proofreading procedure

Display of the result of downloads and visits, as well as the number of cited articles

Maximum dissemination of your research work

Submit your manuscript at: http://papersubmission.scirp.org/

Or contact oje@scirp.org 